\title{
Apolipoprotein E gene polymorphism and the risk of intracerebral hemorrhage: a meta-analysis of epidemiologic studies
}

Rongjun Zhang, Xiaofeng Wang ${ }^{*}$, Zongchun Tang, Jianxin Liu, Shuzhen Yang, Youbing Zhang, Yijun Wei, Wenyin Luo, Jun Wang, Jialong Li, Bobo Chen and Kunhu Zhang

\begin{abstract}
Background: Studies investigating the association between the apolipoprotein E (APOE) gene polymorphism and the risk of intracerebral hemorrhage $(\mathrm{ICH})$ have reported conflicting results. We here performed a meta-analysis based on the evidence currently available from the literature to make a more precise estimation of this relationship.

Methods: Published literature from the National Library of Medline and Embase databases were retrieved. Odds ratio $(\mathrm{OR})$ and $95 \%$ confidence interval $(\mathrm{Cl})$ were calculated in fixed- or random-effects models when appropriate. Subgroup analyses were performed by race.

Results: This meta-analysis included 11 case-control studies, which included 1,238 ICH cases and 3,575 controls. The combined results based on all studies showed that ICH cases had a significantly higher frequency of APOE $\varepsilon 4$ allele (OR=1.42, $95 \% \mathrm{Cl}=1.21,1.67, \mathrm{P}<0.001)$. In the subgroup analysis by race, we also found that ICH cases had a significantly higher frequency of $\mathrm{APOE} \varepsilon 4$ allele in Asians $(\mathrm{OR}=1.52,95 \% \mathrm{Cl}=1.20,1.93, \mathrm{P}<0.001)$ and in Caucasians $(\mathrm{OR}=1.34,95 \% \mathrm{Cl}=1.07,1.66, \mathrm{P}=0.009)$. There was no significant relationship between APOE $\varepsilon 2$ allele and the risk of ICH.
\end{abstract}

Conclusion: Our meta-analysis suggested that APOE $\varepsilon 4$ allele was associated with a higher risk of ICH.

Keywords: Apolipoprotein E, Intracerebral hemorrhage, Gene polymorphism, Meta-analysis

\section{Introduction}

Intracerebral hemorrhage $(\mathrm{ICH})$ occurs at an annual incidence rate of 15 to 19 per 100,000 [1]. ICH accounts for approximately $15 \%$ of acute strokes in the United States and 22-35\% in Asian populations [2-5]. ICH can be a devastating type of stroke, and the 30-day case mortality rate of $\mathrm{ICH}$ is $40 \%$ to $50 \%$. [2,6]. A pooled prospective study found that the risk factors for $\mathrm{ICH}$ were older age, African-American ethnicity, hypertension, lower LDL-C, and lower triglycerides [7]. ICH has been shown to have important genetic and environmental risk factors.

Apolipoprotein E (APOE) gene, located on the long arm of chromosome 19, codes for a 299-amino acid protein (apoE). ApoE is a polymorphic glycoprotein involved in cholesterol transport and cell membrane maintenance and repair $[8,9]$. APOE has three common

\footnotetext{
* Correspondence: xfwang13@hotmail.com

Department of Neurosurgery, Third Hospital of Chinese PLA, 45 Dongfeng Road, Jin Tai District, Baoji 721004, Shanxi Province, China
}

alleles: epsilon $2(\varepsilon 2), \varepsilon 3$, and $\varepsilon 4$ that encode the three major isoforms of apoE: E2, E3, and E4, which performs isoform-dependent neurotrophic and antioxidant functions [8,10-12]. Each person has 2 alleles that together compose that person's $A P O E$ genotype (e.g., $\varepsilon 2 / \varepsilon 3$ or $\varepsilon 3 /$ $\varepsilon 3) . A P O E$ is one of the most widely studied genes in vascular and neurodegenerative diseases [13].

Recently, some studies have been conducted to clarify the association between $A P O E$ gene polymorphisms and the risk of ICH [14-24]. However, previous studies investigating the association have reported conflicting results $[25,26]$. We here performed a meta-analysis based on the evidence currently available from the literature to make a more precise estimation of this relationship.

\section{Materials and methods}

\section{Literature search strategy}

We used a detailed electronic search strategy in Medline and Embase from 1950 to the end of March 2013. Two 
authors independently searched the databases using following key words in all relevant combinations: 'cerebral' or 'intracerebral' or 'intracranial', 'hemorrhage', 'apolipoprotein $\mathrm{E}^{* \text { ' }}$ or 'ApoE ${ }^{*}$, 'polymorphism' or 'allele' or 'genotype' or 'variant'. The search was conducted without limitation on language. The reference lists of all retrieved publications were scrutinized for additional studies. If studies had partially overlapping subjects, the smaller dataset was excluded. If necessary, we attempted to contact the principal investigators of retrieved articles to require additional data.

\section{Inclusion and exclusion criteria}

The following criteria were used to include published studies: (i) independent epidemiological studies (for humans only); (ii) a clear description of $A P O E$ allele in $\mathrm{ICH}$ cases and controls; (iii) sufficient allele data were presented to calculate the odds ratio (OR) and 95\% confidence interval (CI); Major reasons for exclusion of studies were (i) no control; (ii) not an original paper (e.g. review or letter etc.); (iii) duplicate publications.

\section{Data extraction}

Data were extracted by two authors independently, and disagreements were resolved by consensus. When a study did not explicitly report one or more of the requested data, we contacted the author of the study for additional details. The following data were extracted: the last name of the first author, publication year, country, study design, genotyping method, sample size and the results of studies.

\section{Statistical analysis}

All analyses were performed using STATA 11.0 (StataCorp LP, College Station, TX, USA). The Mantel-Haenszel method for fixed effects and the Der-Simonian-Laird method for random effects were used to estimate pooled OR and corresponding 95\% CI. Meta-analysis heterogeneity was quantified by computing Cochrane's $Q$ and corresponding $P$-value and $\mathrm{I}^{2}$ (percent of effect size attributable to heterogeneity). We used fixed-effects methods if the result of the Q test was not significant. Otherwise, we calculated pooled estimates and confidence intervals assuming a random-effects model. Also, subgroup analyses were performed on the basis of race. In this study, $P<0.05$ was considered statistically significant. Publication bias was assessed by visual inspection of funnel plots, the Begg's rank correlation method and the Egger's weighted regression method.

\section{Results}

\section{Study characteristics}

Characteristics of studies included in the meta-analysis are summarized in Table 1 . Our initial search identified 108 studies according to the search words. Through the step of screening the title, abstracts, 85 articles were excluded, leaving 23 articles for full publication review. Of these, 12 were excluded [25-36]. Finally, a total of 11 studies were included in our meta-analysis [14-24], which included 1,238 ICH cases and 3,575 controls. Of those, three studies were population-based case-control studies, and eight studies were hospital-based case-control studies. Studies were conducted in USA, United Kingdom, Portugal, Japan, India and China. The frequencies of apolipoprotein $\mathrm{E}$ alleles of studies included in the meta-analysis were shown in Table 2.

\section{Quantitative synthesis}

The combined results based on all studies showed that $\mathrm{ICH}$ cases had a significantly higher frequency of $A P O E$ $\varepsilon 4$ allele $(\mathrm{OR}=1.42,95 \% \mathrm{CI}=1.21,1.67, P<0.001)$ (Figure 1$)$ (Table 3$)$. In the subgroup analysis by race, we also found

Table 1 Characteristics of studies included in the meta-analysis

\begin{tabular}{|c|c|c|c|c|c|c|}
\hline Study (author, year) & Design & Study period & Population (country) & Genotyping method & No. of cases & No. of controls \\
\hline Nakata 1997 & $\mathrm{HCC}$ & 1992-1995 & Asians (Japan) & $P C R$ & 38 & 38 \\
\hline McCarron 1998 & $\mathrm{HCC}$ & DNR & Caucasians (United Kingdom) & PCR & 71 & 406 \\
\hline Garcia 1999 & PCC & DNR & Caucasians (Portugal) & PCR-RFLP & 48 & 173 \\
\hline Kokubo 2000 & PCC & 1997-1999 & Asians (Japan) & PCR-RFLP & 84 & 1126 \\
\hline Catto 2000 & $\mathrm{HCC}$ & 1997 & Caucasians (United Kingdom) & PCR & 60 & 289 \\
\hline Chowdhury 2001 & $\mathrm{HCC}$ & 1998-1999 & Asians (Japan) & PCR-RFLP & 80 & 190 \\
\hline Woo 2002 & PCC & $1997-2000$ & Caucasians (USA) & PCR & 188 & 366 \\
\hline Woo 2005 & $\mathrm{HCC}$ & 1997-2002 & Caucasians (USA) & TaqMan & 172 & 339 \\
\hline Chen 2009 & $\mathrm{HCC}$ & DNR & Asians (China) & PCR & 217 & 280 \\
\hline Zhang 2012 & $\mathrm{HCC}$ & 2008-2010 & Asians (China) & PCR-RFLP & 180 & 180 \\
\hline Misra 2012 & $\mathrm{HCC}$ & DNR & Asians (India) & PCR & 100 & 188 \\
\hline
\end{tabular}

Abbreviations: HCC Hospital-based case-control, PCC Population-based case-control, DNR Data not reported, PCR Polymerase chain reaction, RFLP Restriction fragment length polymorphism. 
Table 2 Frequencies of apolipoprotein $\mathrm{E}$ alleles of studies included in the meta-analysis

\begin{tabular}{|c|c|c|c|c|c|c|}
\hline Study (author, year) & $\varepsilon 2$ of cases & $\varepsilon 3$ of cases & $\varepsilon 4$ of cases & $\varepsilon 2$ of controls & $\varepsilon 3$ of controls & $\varepsilon 4$ of controls \\
\hline Nakata 1997 & 3 & 32 & 3 & 2 & 32 & 4 \\
\hline McCarron 1998 & 18 & 89 & 35 & 66 & 599 & 147 \\
\hline Garcia 1999 & 4 & 84 & 8 & 14 & 298 & 34 \\
\hline Kokubo 2000 & 14 & 131 & 23 & 103 & 1913 & 236 \\
\hline Catto 2000 & 5 & 95 & 20 & 44 & 446 & 88 \\
\hline Chowdhury 2001 & 2 & 146 & 12 & 13 & 333 & 34 \\
\hline Woo 2002 & 39 & 96 & 53 & 64 & 206 & 96 \\
\hline Woo 2005 & 15 & 118 & 39 & 25 & 266 & 48 \\
\hline Chen 2009 & 33 & 359 & 42 & 44 & 479 & 37 \\
\hline Zhang 2012 & 26 & 280 & 54 & 26 & 314 & 20 \\
\hline Misra 2012 & 7 & 183 & 10 & 15 & 343 & 18 \\
\hline
\end{tabular}

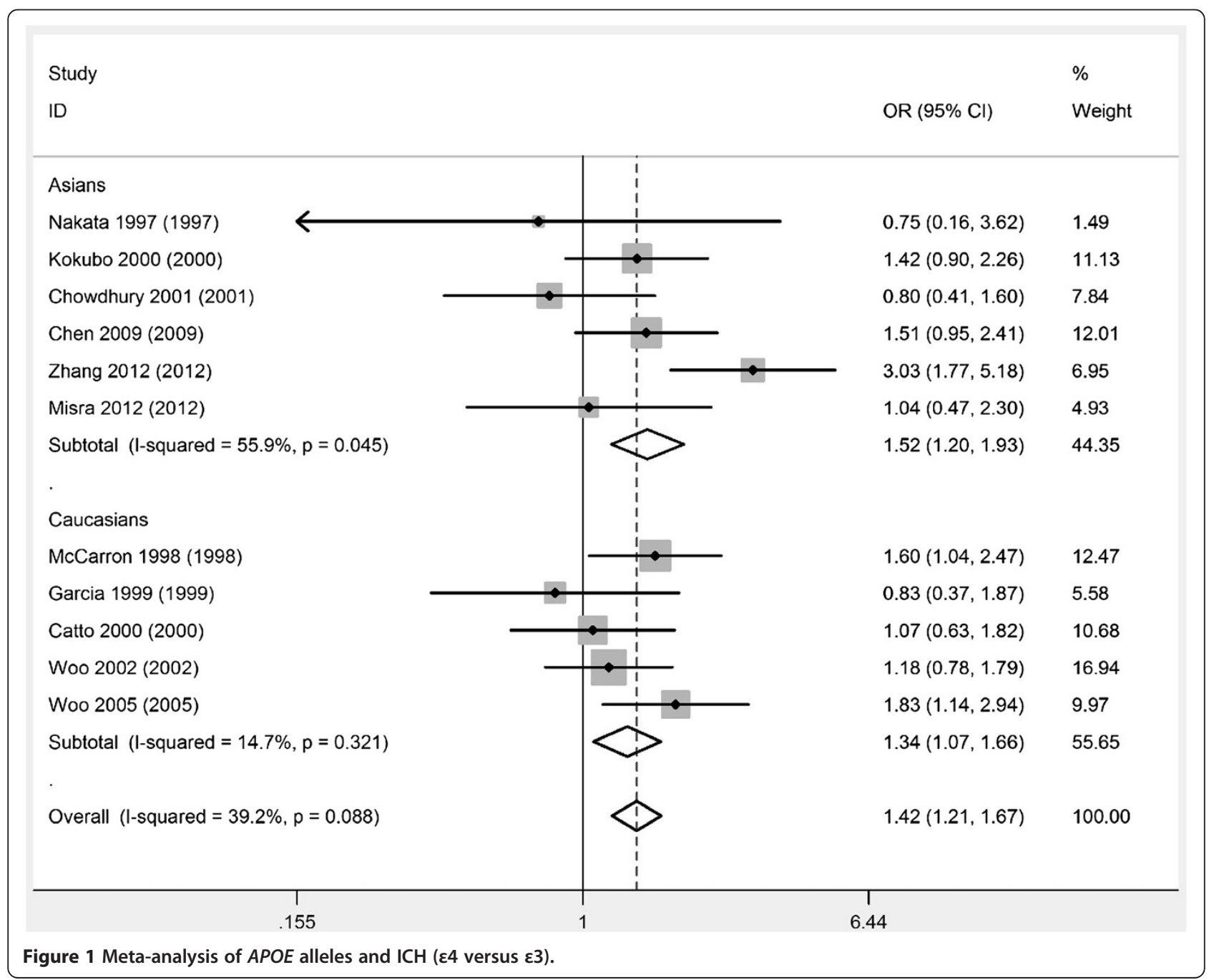


Table 3 Meta-analysis of apolipoprotein E alleles and intracerebral hemorrhage risk

\begin{tabular}{|c|c|c|c|c|c|c|c|}
\hline & $\begin{array}{l}\text { No. of } \\
\text { studies }\end{array}$ & $\begin{array}{l}\text { OR (95\% Cl) } \\
\varepsilon 4 \text { versus ع3 }\end{array}$ & $P$ of $\mathrm{OR}$ & $\begin{array}{l}P \text { of } \\
\text { heterogeneity }\end{array}$ & $\begin{array}{l}\text { OR (95\% Cl) } \\
\varepsilon 2 \text { versus } \varepsilon 3\end{array}$ & $P$ of OR & $\begin{array}{l}P \text { of } \\
\text { heterogeneity }\end{array}$ \\
\hline All & 11 & $1.42(1.21,1.67)$ & $<0.001$ & 0.09 & $1.18(0.96,1.44)$ & 0.11 & 0.29 \\
\hline Asians & 6 & $1.52(1.20,1.93)$ & $<0.001$ & 0.05 & $1.11(0.83,1.47)$ & 0.47 & 0.25 \\
\hline Caucasians & 5 & $1.34(1.07,1.66)$ & 0.009 & 0.32 & $1.26(0.94,1.68)$ & 0.12 & 0.28 \\
\hline
\end{tabular}

Abbreviations: OR Odds ratio, $\mathrm{Cl}$ Confidence interval.

that $\mathrm{ICH}$ cases had a significantly higher frequency of $A P O E \& 4$ allele in Asians $(\mathrm{OR}=1.52,95 \% \mathrm{CI}=1.20,1.93$, $P<0.001)$ and in Caucasians $(\mathrm{OR}=1.34,95 \% \mathrm{CI}=1.07,1.66$, $P=0.009$ ) (Figure 1) (Table 3). There was no significant relationship between $A P O E \& 2$ allele and the risk of $\mathrm{ICH}$ (Figure 2) (Table 3).

\section{Heterogeneity analysis and publication bias}

Statistical heterogeneity was not found among studies in overall comparisons by using the Q statistic (Table 3). Publication bias was not found by the Begg's rank correlation method (Figure 3) or Egger weighted regression method (Figure 4).

\section{Discussion}

There is evidence for a role of genetic factors in the development of ICH. Studies investigating the association between genetic polymorphisms and ICH risk are being reported with rapidly increasing frequency. Endoglin gene polymorphism was a risk factor for sporadic ICH [37]. A comparative study that angiotensin converting enzyme (ACE) gene DD homozygosity of the I/D polymorphism in

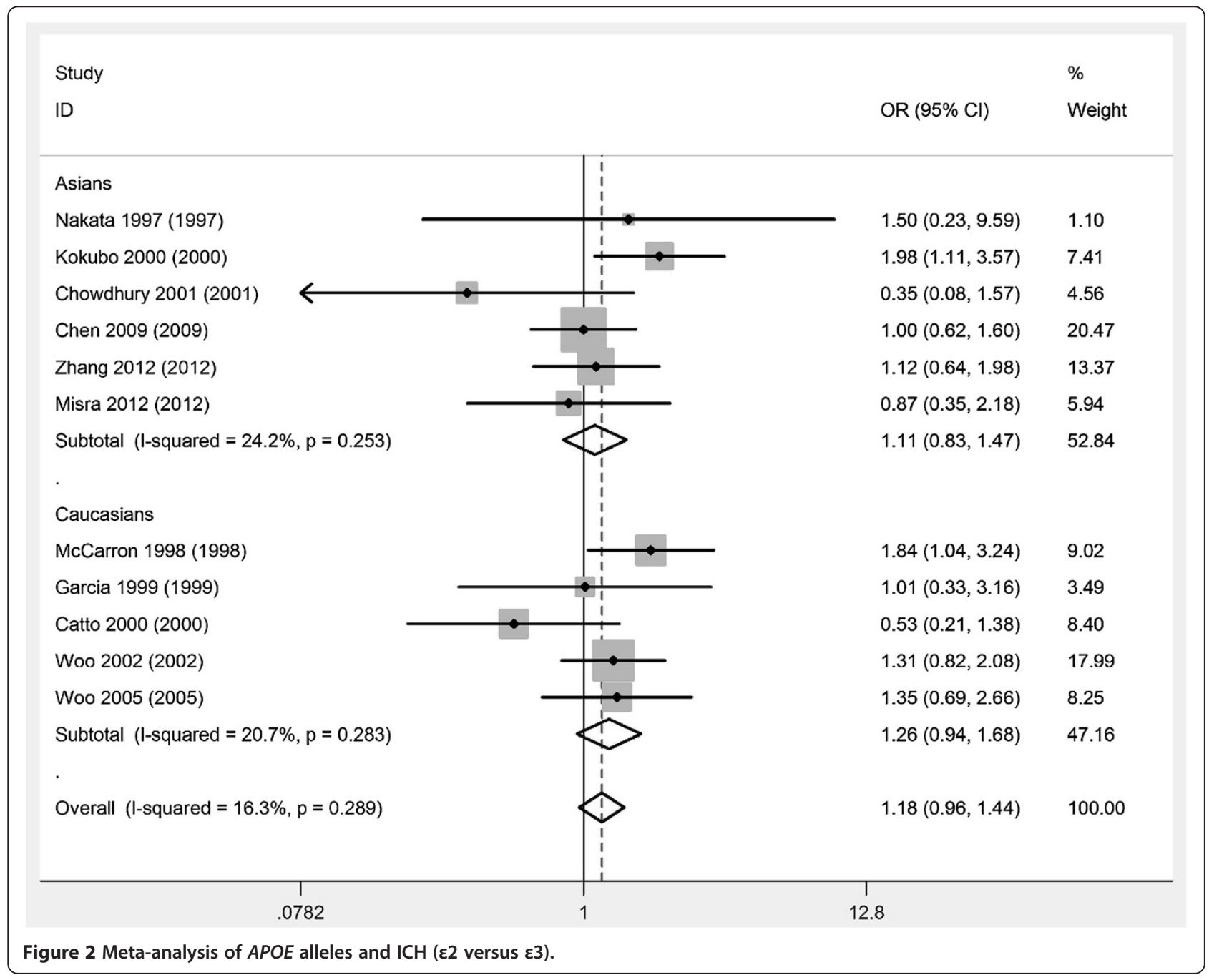




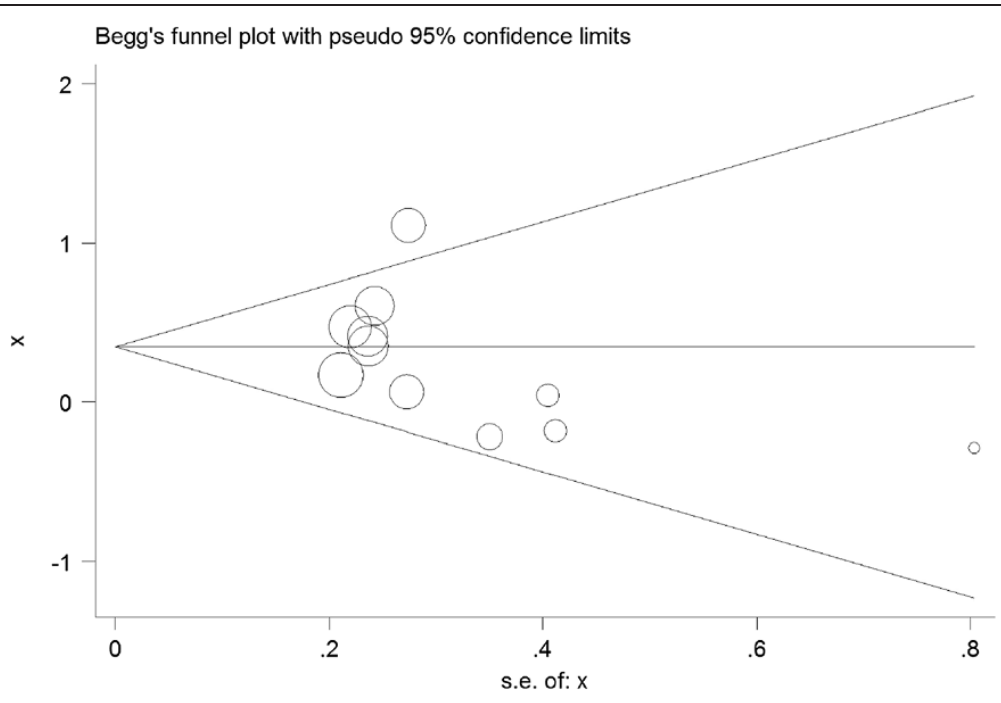

Figure 3 Begg's publication bias plot of APOE alleles and ICH.

intron 16 is an independent risk factor for $\mathrm{ICH}$ in a Polish population [38]. A case-control study suggested that the beta1-tubulin Q43P polymorphism could be associated with $\mathrm{ICH}$ in men from southern Spain [39]. A populationbased prospective nested case-control study found that estrogen receptor alpha gene polymorphisms were associated with first-ever $\mathrm{ICH}$, particularly in combination with hypertension [40]. A case-control study found that glutathione peroxidase 1 C593T polymorphism was associated with lobar ICH in a Polish population [41]. A case-control study suggested that the rs2228048 of TGFBR2 gene may be associated with development of ICH in Korean population [42]. A study suggested that the rs17222919 of ALOX5AP may be associated with the development of $\mathrm{ICH}$ in Korean population [43].
The APOE gene polymorphisms are associated with many other diseases. A meta-analysis showed that $A P O E \& 4$ allele appeared to be associated with a higher prevalence of dementia in Parkinson disease [44]. A meta-analysis suggested that the APOE $\varepsilon 4$ isoform was a genetic factor that might influence the age at onset of temporal lobe epilepsy [45]. A meta-analysis showed that the $A P O E \& 4$ allele was associated with an increased risk of developing hypertension [46]. A metaanalysis found that the APOE \&4 allele was associated with a moderately increased risk for progression from mild cognitive impairment to Alzheimer's disease-type dementia [47]. Prevalence of $A P O E$ \&4 alleles was significantly higher in patients with coronary artery disease than controls [48].

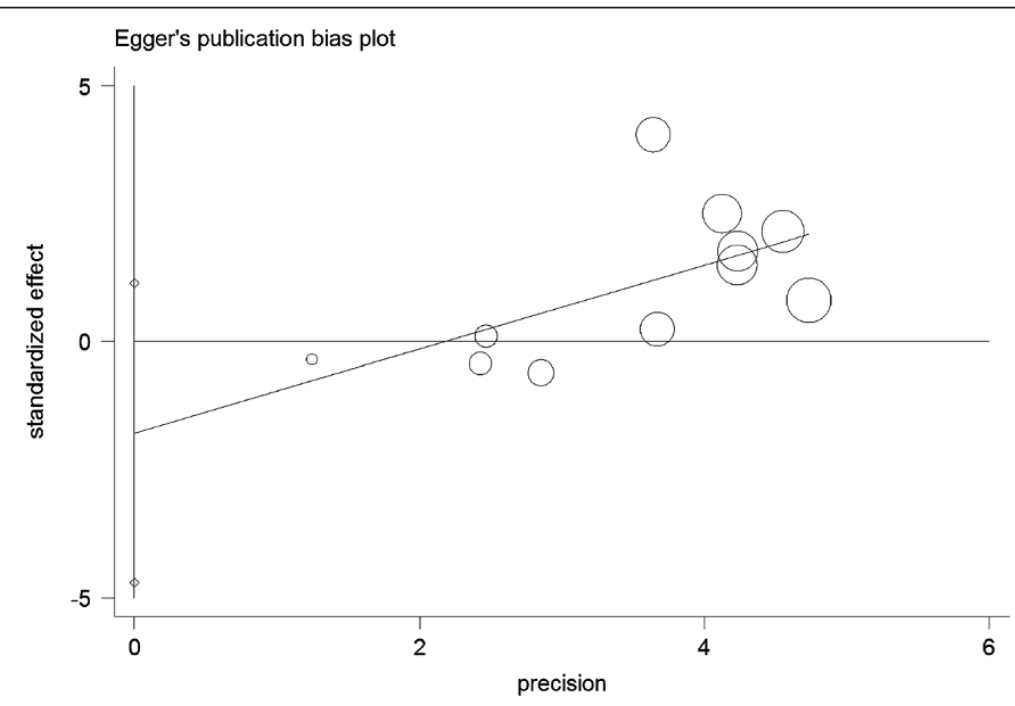

Figure 4 Egger's publication bias plot of $A P O E$ alleles and ICH. 
The exact mechanism of the association between $A P O E$ polymorphism and the risk of $\mathrm{ICH}$ remains unclear. $A P O E$ plays a critical role in redistributing lipids among central nervous system cells for normal lipid homeostasis [49], repairing injured neurons [50], maintaining synaptodendritic connections [51], neurite outgrowth [52], synaptic plasticity [53], mitochondrial resistance to oxidative stress [54], and glucose use by neurons and glial cells [25]. Compared with $\varepsilon 3 / \varepsilon 3, \varepsilon 4$ allele-containing genotypes are associated with increased total cholesterol levels [13]. It appears that the $\varepsilon 4$ allele enhances amyloid deposition in blood vessels [55]. Thus, one might expect $\varepsilon 4$ carriers to have increased susceptibility to $\mathrm{ICH}$, especially in a lobar location. Furthermore, $A P O E \& 4$ allele was also associated with an increased risk of developing hypertension [46], which may be the reason that $A P O E \& 4$ allele was associated with a higher risk of $\mathrm{ICH}$.

Several limitations of our meta-analysis should be noted. First of all, meta-analysis is powerful but also controversial-controversial because several conditions are critical to a sound meta-analysis, and small violations of those conditions can lead to misleading results [56]. Second, relatively small sample size of studies in overall comparisons was observed in this meta-analysis. The results of small meta-analyses should be regarded with caution, even if the $P$ value shows extreme statistical significance [57]. Thirdly, because of the lack of individual patient data, we could not perform an adjustment estimate. In spite of these limitations, our meta-analysis also had some advantages. First, the major strengths of the meta-analysis are that we used a comprehensive searching strategy based on computer-assisted and manual searching which allowed the eligible studies to be included as far as possible. Second, no heterogeneity or publication bias was found, which leads to a possibly robust result.

In conclusion, our meta-analysis suggested that $A P O E$ $\varepsilon 4$ allele was associated with a higher risk of ICH. Future studies will be required to clarify the biological implications of our findings.

\section{Competing interests}

The authors declare that they have no conflict of interests.

\section{Authors' contributions}

RJZ, XFW, ZCT, JXL, SZY and YBZ carried out the search studies and drafted the manuscript. YJW, WYL and JW, participated in the design of the study and performed the statistical analysis. JLL, BBC and $\mathrm{KHZ}$ conceived of the study, and participated in its design and coordination and helped to draft the manuscript. All authors read and approved the final manuscript.

\section{Acknowledgements}

The study was supported by grants from the national key Technology R\&D program for the 12th Five-year plan of P.R. China (2011BAI08B05).

Received: 12 September 2013 Accepted: 20 September 2013 Published: 12 March 2014

\section{References}

1. Broderick J, Brott T, Kothari R, Miller R, Khoury J, Pancioli A, Gebel J, Mills D, Minneci L, Shukla R: The greater Cincinnati/Northern Kentucky stroke study: preliminary first-ever and total incidence rates of stroke among blacks. Stroke 1998, 29:415-421

2. Qureshi Al, Tuhrim S, Broderick JP, Batjer HH, Hondo H, Hanley DF: Spontaneous intracerebral hemorrhage. N Engl J Med 2001, 344:1450-1460

3. Mohr JP, Caplan LR, Melski JW, Goldstein RJ, Duncan GW, Kistler JP, Pessin MS, Bleich HL: The Harvard cooperative stroke registry: a prospective registry. Neurology 1978, 28:754-762.

4. Hu HH, Sheng WY, Chu FL, Lan CF, Chiang BN: Incidence of stroke in Taiwan. Stroke 1992, 23:1237-1241.

5. Zhang LF, Yang J, Hong Z, Yuan GG, Zhou BF, Zhao LC, Huang YN, Chen J, Wu YF, Collaborative Group of China Multicenter Study of Cardiovascular E: Proportion of different subtypes of stroke in China. Stroke 2003, 34:2091-2096.

6. Broderick JP, Brott T, Tomsick T, Huster G, Miller R: The risk of subarachnoid and intracerebral hemorrhages in blacks as compared with whites. N Engl J Med 1992, 326:733-736.

7. Sturgeon JD, Folsom AR, Longstreth WT Jr, Shahar E, Rosamond WD, Cushman M: Risk factors for intracerebral hemorrhage in a pooled prospective study. Stroke 2007, 38:2718-2725.

8. Mahley RW: Apolipoprotein E: cholesterol transport protein with expanding role in cell biology. Science 1988, 240:622-630.

9. Poirier J: Apolipoprotein E in animal models of CNS injury and in Alzheimer's disease. Trends Neurosci 1994, 17:525-530.

10. Al-Khedhairy AA: Apolipoprotein E polymorphism in Saudis. Mol Biol Rep 2004, 31:257-260.

11. Mahfouz RA, Sabbagh AS, Zahed LF, Mahfoud ZR, Kalmoni RF, Otrock ZK, Taher AT, Zaatari GS: Apolipoprotein E gene polymorphism and allele frequencies in the Lebanese population. Mol Biol Rep 2006, 33:145-149.

12. Laskowitz DT, Horsburgh K, Roses AD: Apolipoprotein E and the CNS response to injury. J Cereb Blood Flow Metab 1998, 18:465-471.

13. Eichner JE, Dunn ST, Perveen G, Thompson DM, Stewart KE, Stroehla BC: Apolipoprotein E polymorphism and cardiovascular disease: a HuGE review. Am J Epidemiol 2002, 155:487-495

14. Zhang R, Wang $X$, Liu J, Yang S, Tang Z, Li S, Peng Y, Zhang H, Yang X, Zhou $Y$, Shao W: Apolipoprotein $E$ gene polymorphism and the risk of intracerebral hemorrhage in the Chinese population. Genet Test Mol Biomarkers 2012, 16:63-66.

15. Misra UK, Kalita J, Somarajan BI: Recurrent intracerebral hemorrhage in patients with hypertension is associated with APOE gene polymorphism: a preliminary study. J Stroke Cerebrovasc Dis 2013, 22:758-763.

16. Chen YC, Lee-Chen GJ, Wu YR, Hu FJ, Wu HC, Kuo HC, Chu CC, Ryu SJ, Chen ST, Chen CM: Analyses of interaction effect between apolipoprotein E polymorphism and alcohol use as well as cholesterol concentrations on spontaneous deep intracerebral hemorrhage in the Taiwan population. Clin Chim Acta 2009, 408:128-132.

17. Woo D, Kaushal R, Chakraborty R, Woo J, Haverbusch M, Sekar P, Kissela B, Pancioli A, Jauch E, Kleindorfer D, Flaherty M, Schneider A, Khatri P, Sauerbeck L, Khoury J, Deka R, Broderick J: Association of apolipoprotein E4 and haplotypes of the apolipoprotein E gene with lobar intracerebral hemorrhage. Stroke 2005, 36:1874-1879.

18. Woo D, Sauerbeck LR, Kissela BM, Khoury JC, Szaflarski JP, Gebel J, Shukla R, Pancioli AM, Jauch EC, Menon AG, Deka R, Carrozzella JA, Moomaw CJ, Fontaine RN, Broderick JP: Genetic and environmental risk factors for intracerebral hemorrhage: preliminary results of a population-based study. Stroke 2002, 33:1190-1195.

19. Chowdhury AH, Yokoyama T, Kokubo Y, Zaman MM, Haque A, Tanaka H: Apolipoprotein E genetic polymorphism and stroke subtypes in a Bangladeshi hospital-based study. J Epidemiol 2001, 11:131-138.

20. Catto AJ, McCormack LJ, Mansfield MW, Carter AM, Bamford JM, Robinson P, Grant PJ: Apolipoprotein E polymorphism in cerebrovascular disease. Acta Neurol Scand 2000, 101:399-404.

21. Kokubo Y, Chowdhury AH, Date C, Yokoyama T, Sobue H, Tanaka H: Agedependent association of apolipoprotein E genotypes with stroke subtypes in a Japanese rural population. Stroke 2000, 31:1299-1306.

22. Garcia C, Pinho e Melo T, Rocha L, Lechner MC: Cerebral hemorrhage and apoE. J Neurol 1999, 246:830-834.

23. McCarron MO, Nicoll JA: High frequency of apolipoprotein E epsilon 2 allele is specific for patients with cerebral amyloid angiopathy-related haemorrhage. Neurosci Lett 1998, 247:45-48. 
24. Nakata Y, Katsuya T, Rakugi H, Takami S, Sato N, Kamide K, Ohishi M, Miki T, Higaki J, Ogihara T: Polymorphism of angiotensin converting enzyme, angiotensinogen, and apolipoprotein E genes in a Japanese population with cerebrovascular disease. Am J Hypertens 1997, 10:1391-1395.

25. Biffi A, Sonni A, Anderson CD, Kissela B, Jagiella JM, Schmidt H, JimenezConde J, Hansen BM, Fernandez-Cadenas I, Cortellini L, Ayres A, Schwab K, Juchniewicz K, Urbanik A, Rost NS, Viswanathan A, Seifert-Held T, Stoegerer EM, Tomas M, Rabionet R, Estivill X, Brown DL, Silliman SL, Selim M, Worrall BB, Meschia JF, Montaner J, Lindgren A, Roquer J, Schmidt R et al: Variants at APOE influence risk of deep and lobar intracerebral hemorrhage. Ann Neurol 2010, 68:934-943.

26. Sudlow C, Martinez Gonzalez NA, Kim J, Clark C: Does apolipoprotein E genotype influence the risk of ischemic stroke, intracerebral hemorrhage, or subarachnoid hemorrhage? Systematic review and meta-analyses of 31 studies among 5961 cases and 17,965 controls. Stroke 2006, 37:364-370.

27. Fontanella M, Rainero I, Gallone S, Rubino E, Rivoiro C, Valfre W, Garbossa D, Nurisso C, Ducati A, Pinessi L: Lack of association between the apolipoprotein E gene and aneurysmal subarachnoid hemorrhage in an Italian population. J Neurosurg 2007, 106:245-249.

28. Tang J, Zhao J, Zhao Y, Wang S, Chen B, Zeng W: Apolipoprotein E epsilon4 and the risk of unfavorable outcome after aneurysmal subarachnoid hemorrhage. Surg Neurol 2003, 60:391-396. discussion 396-397.

29. Nicoll JA, McCarron MO: APOE gene polymorphism as a risk factor for cerebral amyloid angiopathy-related hemorrhage. Amyloid 2001, 8(Suppl 1):51-55.

30. McCarron MO, Nicoll JA, Stewart J, Ironside JW, Mann DM, Love S, Graham DI, Dewar D: The apolipoprotein E epsilon2 allele and the pathological features in cerebral amyloid angiopathy-related hemorrhage. J Neuropathol Exp Neurol 1999, 58:711-718.

31. McCarron MO, Nicoll JA, Ironside JW, Love S, Alberts MJ, Bone I: Cerebra amyloid angiopathy-related hemorrhage. Interaction of APOE epsilon2 with putative clinical risk factors. Stroke 1999, 30:1643-1646.

32. McCarron MO, Hoffmann KL, DeLong DM, Gray L, Saunders AM, Alberts MJ: Intracerebral hemorrhage outcome: apolipoprotein E genotype, hematoma, and edema volumes. Neurology 1999, 53:2176-2179.

33. Nicoll JA, Burnett C, Love S, Graham DI, Dewar D, Ironside JW, Stewart J, Vinters HV: High frequency of apolipoprotein E epsilon 2 allele in hemorrhage due to cerebral amyloid angiopathy. Ann Neurol 1997, 41:716-721.

34. Nicoll JA, Burnett C, Love S, Graham DI, Ironside JW, Vinters HV: High frequency of apolipoprotein E epsilon 2 in patients with cerebral hemorrhage due to cerebral amyloid angiopathy. Ann Neurol 1996, 39:682-683.

35. Greenberg SM, Briggs ME, Hyman BT, Kokoris GJ, Takis C, Kanter DS, Kase CS, Pessin MS: Apolipoprotein E epsilon 4 is associated with the presence and earlier onset of hemorrhage in cerebral amyloid angiopathy. Stroke 1996, 27:1333-1337.

36. Greenberg SM, Rebeck GW, Vonsattel JP, Gomez-Isla T, Hyman BT: Apolipoprotein E epsilon 4 and cerebral hemorrhage associated with amyloid angiopathy. Ann Neurol 1995, 38:254-259.

37. Alberts MJ, Davis JP, Graffagnino C, McClenny C, Delong D, Granger C, Herbstreith MH, Boteva K, Marchuk DA, Roses AD: Endoglin gene polymorphism as a risk factor for sporadic intracerebral hemorrhage. Ann Neurol 1997, 41:683-686

38. Slowik A, Turaj W, Dziedzic T, Haefele A, Pera J, Malecki MT, GlodzikSobanska L, Szermer P, Figlewicz DA, Szczudlik A: DD genotype of ACE gene is a risk factor for intracerebral hemorrhage. Neurology 2004, 63:359-361.

39. Navarro-Nunez L, Lozano ML, Rivera J, Corral J, Roldan V, Gonzalez-Conejero $R$, Iniesta JA, Montaner J, Vicente $V$, Martinez $C$ : The association of the beta1-tubulin Q43P polymorphism with intracerebral hemorrhage in men. Haematologica 2007, 92:513-518.

40. Strand M, Soderstrom I, Wiklund PG, Hallmans G, Weinehall L, Soderberg S, Olsson T: Estrogen receptor alpha gene polymorphisms and first-ever intracerebral hemorrhage. Cerebrovasc Dis 2007, 24:500-508.

41. Pera J, Slowik A, Dziedzic T, Pulyk R, Wloch D, Szczudlik A: Glutathione peroxidase 1 C593T polymorphism is associated with lobar intracerebral hemorrhage. Cerebrovasc Dis 2008, 25:445-449.
42. Lim YH, Jeong YS, Kim SK, Kim DH, Yun DH, Yoo SD, Kim HS, Baik HH: Association between TGFBR2 gene polymorphism (rs2228048, Asn389Asn) and intracerebral hemorrhage in Korean population. Immunol Invest 2011, 40:569-580.

43. Kim DH, Ahn WY, Kim DK, Choe BK, Kim SK, Jo DJ, Kim JY, Chung JH, Jeong YS, Yun DH, Yoo SD, Kim HS, Baik HH: A Promoter polymorphism (rs17222919, -1316T/G) of ALOX5AP is associated with intracerebral hemorrhage in Korean population. Prostaglandins Leukot Essent Fatty Acids 2011, 85:115-120.

44. Huang $X$, Chen P, Kaufer DI, Troster Al, Poole C: Apolipoprotein E and dementia in Parkinson disease: a meta-analysis. Arch Neurol 2006, 63:189-193.

45. Kauffman MA, Consalvo D, Moron DG, Lereis VP, Kochen S: ApoE epsilon4 genotype and the age at onset of temporal lobe epilepsy: a casecontrol study and meta-analysis. Epilepsy Res 2010, 90:234-239.

46. Niu W, Qi Y, Qian Y, Gao P, Zhu D: The relationship between apolipoprotein E epsilon2/epsilon3/epsilon4 polymorphisms and hypertension: a meta-analysis of six studies comprising 1812 cases and 1762 controls. Hypertens Res 2009, 32:1060-1066.

47. Elias-Sonnenschein LS, Viechtbauer W, Ramakers $H$, Verhey FR, Visser PJ: Predictive value of APOE-epsilon 4 allele for progression from $\mathrm{MCl}$ to AD-type dementia: a meta-analysis. J Neurol Neurosurg Psychiatry 2011, 82:1149-1156.

48. Rai TS, Khullar M, Sehrawat BS, Ahuja M, Sharma PK, Vijayvergiya R, Grover A: Synergistic effect between apolipoprotein $E$ and apolipoprotein $A 1$ gene polymorphisms in the risk for coronary artery disease. Mol Cell Biochem 2008, 313:139-146

49. Gong JS, Kobayashi M, Hayashi H, Zou K, Sawamura N, Fujita SC, Yanagisawa K, Michikawa M: Apolipoprotein E (ApoE) isoform-dependent lipid release from astrocytes prepared from human ApoE3 and ApoE4 knock-in mice. J Biol Chem 2002, 277:29919-29926.

50. Buttini M, Orth M, Bellosta S, Akeefe H, Pitas RE, Wyss-Coray T, Mucke L, Mahley RW: Expression of human apolipoprotein E3 or E4 in the brains of Apoe-/- mice: isoform-specific effects on neurodegeneration. J Neurosci 1999, 19:4867-4880.

51. Nathan BP, Bellosta S, Sanan DA, Weisgraber KH, Mahley RW, Pitas RE: Differential effects of apolipoproteins E3 and E4 on neuronal growth in vitro. Science 1994, 264:850-852.

52. Bellosta S, Nathan BP, Orth M, Dong LM, Mahley RW, Pitas RE: Stable expression and secretion of apolipoproteins E3 and E4 in mouse neuroblastoma cells produces differential effects on neurite outgrowth. J Biol Chem 1995, 270:27063-27071.

53. Trommer BL, Shah C, Yun SH, Gamkrelidze G, Pasternak ES, Ye GL, Sotak M, Sullivan PM, Pasternak JF, LaDu MJ: ApoE isoform affects LTP in human targeted replacement mice. Neuroreport 2004, 15:2655-2658.

54. Gibson GE, Haroutunian V, Zhang H, Park LC, Shi Q, Lesser M, Mohs RC, Sheu RK, Blass JP: Mitochondrial damage in Alzheimer's disease varies with apolipoprotein E genotype. Ann Neurol 2000, 48:297-303.

55. McCarron MO, Nicoll JA: Apolipoprotein E genotype and cerebral amyloid angiopathy-related hemorrhage. Ann N Y Acad Sci 2000, 903:176-179.

56. Walker E, Hernandez AV, Kattan MW: Meta-analysis: Its strengths and limitations. Cleve Clin J Med 2008, 75:431-439.

57. Flather MD, Farkouh ME, Pogue JM, Yusuf S: Strengths and limitations of meta-analysis: larger studies may be more reliable. Control Clin Trials 1997, 18:568-579. discussion 661-566.

doi:10.1186/1476-511X-13-47

Cite this article as: Zhang et al:: Apolipoprotein $\mathrm{E}$ gene polymorphism and the risk of intracerebral hemorrhage: a meta-analysis of epidemiologic studies. Lipids in Health and Disease 2014 13:47. 